\title{
Selection method of new candidates for finfish aquaculture: the case of the French Atlantic, the Channel and the North Sea coasts
}

\author{
Loïc Quéméner, Marc Suquet*, David Mero, Jean-Louis Gaignon \\ Ifremer, Laboratoire de Physiologie des Poissons, BP 70, 29280 Plouzané, France
}

Received 18 March 2002; accepted 5 September 2002

\begin{abstract}
At present, European marine fish farming is based on sea bream and sea bass. A trend for diversification is sustained by the diversity of environmental conditions, by the availability of new production techniques such as recirculating systems, by an increase in rearing yields, by new market trends and by the possibilities to reduce risks of disease outbreak. Already reared fish species were chosen considering a limited number of criteria such as a high selling price and the availability of juveniles or breeders in the wild. This paper proposes a new selection method of fish species as candidates for aquaculture development on the French Atlantic, the Channel and the North Sea coasts. Using a three-phase procedure, candidates were selected among 20000 fish species. Final classification was carried out using a panel of 22 criteria, taking into account inquiries conducted in France with aquaculturists but also with the main actors of distribution and transformation channels and with consumers. Cod (Gadus morhua) was selected by the present work as the first candidate for aquaculture development on the western coasts of France. This work also highlights the high interest of Gadoids for aquaculture development in this area. (C) 2002 Ifremer/CNRS/Inra/IRD/Cemagref/Éditions scientifiques et médicales Elsevier SAS. All rights reserved.
\end{abstract}

\section{Résumé}

Méthode de sélection de nouvelles espèces de poissons marins pour l'aquaculture : cas des côtes françaises de l'Atlantique, de la Manche et de la mer du Nord. En Europe, l'aquaculture marine est basée sur l'élevage de la daurade royale et du bar. La tendance à diversifier est soutenue par la diversité des conditions de l'environnement, par l'émergence de nouvelles techniques de production telles que le circuit fermé, par un accroissement des rendements attendus, par les nouvelles tendances du marché et par la possibilité de réduire les risques pathologiques. Les espèces actuellement élevées ont été choisies en utilisant un nombre limité de critères tels qu'un fort prix de vente et la disponibilité de juvéniles ou reproducteurs dans le milieu naturel. Ce travail propose une nouvelle méthode de sélection de poissons candidats au développement de l'aquaculture sur les côtes françaises de l'Atlantique, de la Manche et de la mer du Nord. En utilisant une procédure constituée de trois phases successives, les candidats sont sélectionnés parmi 20000 espèces de poissons. Une classification finale est effectuée en utilisant un ensemble de 22 critères, prenant en compte les résultats d'enquêtes réalisées en France auprès d'aquaculteurs mais aussi des principaux acteurs des secteurs de la distribution et de la transformation, ainsi qu'auprès des consommateurs. La morue est sélectionnée par cette étude comme premier candidat pour le développement de l'aquaculture sur les côtes ouest de la France ; ce travail met également en évidence le fort potentiel des Gadidés pour le développement de l'aquaculture dans cette région. (C) 2002 Ifremer/CNRS/Inra/IRD/Cemagref/Éditions scientifiques et médicales Elsevier SAS. Tous droits réservés.

Keywords: New species; Species selection; Diversification; Cod; Gadiforms

\section{Introduction}

European marine fish farming focuses on two species, sea bass (Dicentrarchus labrax) and sea bream (Sparus

\footnotetext{
* Corresponding author.

E-mail address: msuquet@ifremer.fr (M. Suquet).
}

aurata) for which the production reached $120000 \mathrm{t}$ in 2000 on the Mediterranean coasts. The need to diversify the number of reared fish species has been claimed in the past (Avault, 1993; Lensi, 1995) as well as at present (Paquotte, 1998; New, 1999). Such a trend is sustained by several reasons.

First, the rearing capacity of fish is highly dependent on the environment, fish being poikilotherm animals. The wide 
range of environmental conditions met by aquaculturists requires the availability of a panel of species among which the farmers will select fish well adapted to their own environment. Second, aquaculture uses a wide range of production techniques, ranging from extensive management of fjords or lagoons up to highly intensive recirculating systems. Finfish species must be adapted to these very different rearing constraints. Third, a high increase in the production yield of farms can be expected by rearing new candidate fish species: after 30 years of research, the growth capacity of sea bass is still limited reaching a weight of $400 \mathrm{~g}$ after 2 years. In the wild, the growth performances of some promising candidates are greater, reaching $1 \mathrm{~kg}$ (wreckfish, Polyprion americanus; Kentouri et al., 1995) and up to 5-10 kg (bluefin tuna, Thunnus thynnus; Iioka et al., 2000) in 1 year. Fourth, the market share of fish cuts has largely increased in Europe. In France, a 45\% increase of the initial value of this product was observed between 1987 and 1997. New candidates must be adapted to this soaring market share. Fifth, because of nodavirus, the Mediterranean sea bass production was checked in 1994-1995 (Basurco and Abellan, 2000). A part of this production was switched to sea bream, showing that widening the number of cultured species contributes to reducing the risk of disease outbreak.

A significant increase in the number of studies related to "new species" for aquaculture has been observed. At present, 25 marine fish species are being investigated in the Mediterranean area (Marino, unpublished data). These species are most often chosen using a limited number of criteria close to those used in the early 1970s for sea bass selection: a high selling price and the availability of juveniles or breeders in the wild.

In nine fish species initially selected as promising candidates for finfish aquaculture, the expansion ratio observed for rearing between 1987 and 1996 ranged from -1.5 up to $210.3 \%$ of the initial volume, depending on the species (New, 1999). Furthermore, the time period for routine seed supply in the "new fish species" may require 3-10 years (Muir and Young, 1998). These two facts sustain a careful selection of new candidates species in order to avoid a subsequent waste of time in the development of fish farming of these species.

A few selection methods of "new fish species" have been proposed. However, they are limited to a checklist of requirements (Avault, 1993), to a low number of selection criteria (Davis et al., 1998), to a panel of criteria without practical validation (Parfouru, unpublished data) or to a low number of candidate species (Benetti et al., 1999). The most interesting method was proposed by Le François et al. (2002) in order to sustain the species diversification of the aquaculture industry of the province of Quebec (Canada). This work assessed the potential of candidates for three development strategies (complete life cycle, stock enhancement and on-growing of juveniles). However, these authors started from a non-exhaustive list of 45 fish species previously selected for their commercial interest.

The aim of the present paper is to propose a selection method of new candidates for finfish aquaculture. This study is not an a posteriori justification of the candidature of fish species in which a limited rearing experience has already been carried out. That is why candidates were identified among 20000 species, allowing the selection of true "new species" in which no rearing experience is available. This work used a large panel of biological and market criteria but no rearing performances recorded during previous experiments. Because of its soaring role, standard quality product, i.e. fish flesh at low cost and ready to cook, is the targeted market share of this study. From a zootechnical point of view, targeting this market segment requires species easy to rear, presenting a high growth rate and low production costs (Paquotte, 1998). Species are selected for open rearing systems such as tanks or cages. Promising species well adapted to rearing conditions of the French Atlantic, the Channel and the North Sea coasts are pointed out in this work.

\section{Material and methods}

The selection method was based on a three-phase procedure. For the first two phases, species were selected using Access 97 software. For the third phase, the classification of finfish species was carried out using Electre III software (Vallée and Zielniewicz, 1994), a multiple criteria decision making method (Roy and Bouissou, 1993). Selection criteria were settled taking into account inquiries conducted with French aquaculturists (Quéméner and Gaignon, unpublished data), with the main actors of the French transformation (13 companies selected among the most important ones in France) and distribution (11 companies representing $80 \%$ of the national turnover of this sector) channels (Thomas, 2000) and also with consumer requirements (OFIMER, 1999) (in the present work, these profiles were, respectively, called production, transformation, distribution and consumption).

Data were mainly selected from "Fishbase" (Fishbase, 1998) offering information on over 20000 fish species concerning their biology and fishery. When additional information was collected from scientific literature and from wholesale fishmongers, data sources are given for each criterion. Fish species whose production by aquaculture reaches more than $100 \mathrm{t}$ are not considered as "new species" in this study. However, five control species were maintained in order to verify the validity of the selection method (Table 1).

The three successive phases of the selection method are the following ones. 
Table 1

Control species included in this work

\begin{tabular}{ll}
\hline Common name & Latin name \\
\hline Atlantic salmon & Salmo salar \\
Sea bass & Dicentrarchus labrax \\
Sea bream & Sparus aurata \\
Sea trout & Salmo trutta trutta \\
Turbot & Psetta maxima \\
\hline
\end{tabular}

\subsection{Phase 1: settlement of the mother population}

Among the 20000 species included in Fishbase (1998), fish species were eliminated for the following reasons:

Systematic: species whose morphology is very distant from that of commercial species but also archaic species: superclass Agnatha, superclass Gnathostomata (class Chondrichthyes: Holocephalans; class Osteichthyes, subclass Sarcopterygii and in subclass Actinopterygii: infraclass Cladistia and in infraclass Neopterygii: division Ginglymodi and Halecostomi).

Dangerous or non-eatable species: species dangerous to human (poisonous to eat and traumatogenic).

Electrogenic activity: species able to generate strong electric fields.

Environment: species occurring in boreal and polar environments but also species living in water below $200 \mathrm{~m}$.

Salinity: species never occurring in sea water whatever their stage of life.

Minimum weight: species never reaching a weight of $50 \mathrm{~g}$.

Minimum length: species never reaching a length of $16 \mathrm{~cm}$.

Threatened species: threatened with extinction species (CITES, Convention for International Trade of Endangered Species, Annex 1).

Fish species emerging from this first phase belong to a mother population, which can be used for different geographical cases.

\subsection{Phase 2: the geographical case/elimination part}

Since species cannot be selected whatever their distribution, a specific geographic case was settled: the case of the French Atlantic, the Channel and the North Sea coasts. Species were selected among those belonging to the mother population, following two criteria:

Geographic distribution: because they are adapted to the rearing environment and because the use of non-indigenous species is often not precautionary (Bartley, 1998), only fish species occurring in zone FAO 27 (north-east Atlantic from the North pole up to the Straits of Gibraltar) were kept (data: Hureau, 1996; Quéro and Vayne, 1997).

Whole sale price: in France, the minimum production cost of rainbow trout or Atlantic salmon is close to $1.5 € / \mathrm{kg}$. That is why fish species presenting a lower whole sale price were eliminated. The mean value of the prices recorded in
1996, 1997 and 1998 were used (data: Statp database, IFREMER).

\subsection{Phase 3: the geographical case/classification part}

Remaining species were classified using the following criteria grouped into nine groups. Units are given for each criterion except for index and notes for which no units were used.

\subsubsection{First group: aquacultural potential}

Biological knowledge: this parameter was estimated by the number of publications related to the fish species in Aquatic Sciences and Fisheries Abstracts (ASFA) base. Published works referring to aquaculture but also to biology and fishery were included because they contribute to a global knowledge of new candidate species (unit: number of publications).

Catches potential: juveniles or breeders caught in the wild are needed to rear "new fish species". This parameter takes into account annual landings of French fisheries but also monthly variations of this production:

Catches potential $=(1 / \mathrm{Cv}) \times$ annual landings,

where $\mathrm{Cv}$ is the mean coefficient of variation of monthly landings recorded in 1996, 1997 and 1998. Because a low variability of monthly landings increases catches potential, $1 / \mathrm{Cv}$ was used in this formula (data: Statp database, IFREMER).

\subsubsection{Second group: adaptation potential to the environment}

Geographic recovery: this parameter specifies the recovery between the geographic distribution of each species and the western coasts of France:

Geographic recovery $=\mathrm{Rr} /$ distance between $\mathrm{Lat}_{\mathrm{m}}$ and Lat $_{\mathrm{s}} \mid \times 100$,

where $\mathrm{Rr}$ is the recovery rate calculated between the geographic distribution area of the studied species and the western coasts of France (from the Belgian border, $51^{\circ} 04$ to the Spanish border, $43^{\circ} 20$ ). $\mathrm{Lat}_{\mathrm{m}}$ represents the latitude of the median of the French western coasts $\left(47^{\circ} 12\right)$ and Lat ${ }_{s}$ the latitude of the 3/4 south part of the geographic distribution of the studied species. The geographic distribution area of the different fish species was reduced by $5 \%$ in its north part and 5\% in its south part, where the species rarely occurred and where their adaptation to environmental conditions could be difficult. Because the temperature is higher and the growth rate is most often faster, a farm must rather be held in the south part of the geographic distribution area of a reared species than in its north one. That is why, Lat considered 3/4 south part of the geographic distribution of each species (data: Hureau, 1996; Quéro and Vayne, 1997). 
Table 2

Notes attributed for fish size taking into account the requirements of the French transformation channel

\begin{tabular}{ll}
\hline Fish length $(\mathrm{cm})$ & Notes \\
\hline $10-30$ & 25 \\
$30-50$ & 35 \\
$50-100$ & 45 \\
\hline
\end{tabular}

Temperature adaptation: this parameter expresses the adaptation capacity of the studied species to a wide range of water temperatures:

Temperature adaptation: latitude north-latitude south of the geographic distribution area of each species (data: Hureau, 1996).

\subsubsection{Third group: growing out potential}

Using data collected in the wild, the weights at 1,2 and 3 years old were calculated from von Bertalanffy functions proposed by Fishbase (unit: g).

\subsubsection{Fourth group: rearing potential}

This group is composed of only one parameter, considering the production potential of aquaculture enterprises:

Rearing potential $=$ whole sale price $\times(1 /$ age at $3 \mathrm{~kg})$.

The weight of $3 \mathrm{~kg}$ represents the optimal weight for the fish flesh transformation channel (Thomas, 2000). For that reason, the age reached at $3 \mathrm{~kg}$ represents the duration of the rearing cycle of each species. This duration is a key factor of farm profitability, not only for the profit, but also to reduce rearing risk potential.

\subsubsection{Fifth group: transformation potential}

This group represents the good adaptation of each species to the transformation process.

Size: following requirements of the French transformation channel, notes were attributed to the candidate species, taking into account their common standard length (Table 2). These notes show the high preference for $50-100 \mathrm{~cm}$ fish with a good tolerance for sizes comprised between 30 and $50 \mathrm{~cm}$.

Profile: lengthened and spindle shaped (note: 2 ), short (1) or eel-like (0).

Section: oval (note: 3), round (2), flat (1) or compressed (0).

Fillet yield: the yield value was used (data: COFREPECHE, 1996; Jolivet, personal communication; Dubois, personal communication; unit: \%).

\subsubsection{Sixth group: practical use potential}

Presence of bones: very few (note: 2), medium (1) or a lot (0) (data: Bykov, 2000; Frimodt, 1995a, b).

\subsubsection{Seventh group: image}

Fish aspect: the species morphology and colour look like the fish aspect determined as "classical" by consumers (note: 2, example: sea bass), is a bit distant from this aspect
(1, European eel; Anguilla anguilla) or very distant (0, anglerfish; Lophius piscatorius).

Reputation: six groups of species were created regarding their annual landing in France (0-1, 1-10, 10-100, 100-1000, 1000-10 000, $10000-100000$ t). The distance of the selling price of each species to the mean selling price of each group was calculated. This distance represents a positive (when placed over the mean group selling price) or negative (when placed under) reputation (data: Statp database, IFREMER).

Species knowledge: the criterion "global spontaneous notoriety" used after the inquiry carried out by Institut d'Observation et de Décision (France) in 1996 (OFIMER, 1999) was used in this work. It considered both the spontaneous capacity of 1101 consumers to cite the name of fish species and their ability to identify this name on a list of fish species (notes: from 0 to 54).

\subsubsection{Eighth group: consumption}

Presentation methods: fish species can be sold fresh, salted, smoked, canned, frozen or following special presentation methods (sushi, sashimi). Each presentation method was noted 1. Because a high number of presentation methods are required by consumers, the value of this criterion is the sum of the presentation methods that can be used for each species (data: Frimodt, 1995a, b; unit: number of methods).

Consumption price: the transformation and distribution channels require the lowest selling price. As a consequence, 1/whole sale price was used (data: Statp database, IFREMER).

\subsubsection{Ninth group: flesh quality}

For the four criteria of this group, data were collected from Bykov (2000) and Frimodt (1995a, b).

Taste: excellent (note: 2), good (1) or low (0).

Colour: consumers require a frank colour of the flesh (note: 1). When this is not the case, a note of 0 was attributed.

Lipids: a lipid content ranging from 5 to $15 \%$ is required by the transformation channel (note: 2 ). The content values lower than $5 \%$ or higher than $15 \%$ are less appreciated (note: 1).

Proteins: because it can be correlated with a low water content, a high protein rate is well appreciated by distribution and transformation channels. For this criterion, the protein content itself was used (unit: \%).

Table 3 represents the weighting coefficient of each of the 22 criteria within each group. In order to take into account the global requirements of the production-consumption line, these coefficients are presented for each of the four profiles: production, transformation, distribution and consumption. The weighting coefficients were attributed according to the results of inquiries conducted in France with aquaculturists, with the main actors of the transformation and distribution channels and with consumers (Quéméner 
Table 3

Weighting coefficients (from 0 to 4 ) attributed to the 22 criteria within a group according to the four profiles of the production-consumption chain

\begin{tabular}{|c|c|c|c|c|c|}
\hline Group & Criteria & Production & Transformation & Distribution & Consumption \\
\hline \multirow[t]{2}{*}{ Aquacultural potential } & Biological knowledge & 1 & 1 & 1 & 1 \\
\hline & Catches potential & 2 & 1 & 1 & 1 \\
\hline \multirow{2}{*}{ Adaptation potential to environment } & Geographic recovery & 3 & 2 & 2 & 2 \\
\hline & Temperature adaptation & 1 & 1 & 1 & 1 \\
\hline \multirow[t]{3}{*}{ Growing out potential } & Weight at 1 year & 4 & 1 & 1 & 1 \\
\hline & Weight at 2 years & 2 & 1 & 1 & 1 \\
\hline & Weight at 3 years & 1 & 1 & 1 & 1 \\
\hline Rearing potential & Rearing potential & 1 & 1 & 1 & 1 \\
\hline \multirow[t]{4}{*}{ Transformation potential } & Size & 1 & 2 & 2 & 2 \\
\hline & Profile & 1 & 2 & 2 & 3 \\
\hline & Section & 1 & 2 & 2 & 3 \\
\hline & Fillet yield & 1 & 1 & 1 & 1 \\
\hline Practical use potential & Presence of bones & 1 & 1 & 1 & 1 \\
\hline \multirow[t]{3}{*}{ Image } & Fish aspect & 1 & 1 & 2 & 1 \\
\hline & Reputation & 3 & 2 & 2 & 3 \\
\hline & Species knowledge & 2 & 1 & 1 & 2 \\
\hline \multirow[t]{2}{*}{ Consumption } & Presentation methods & 2 & 1 & 1 & 1 \\
\hline & Consumption price & 1 & 1 & 1 & 1 \\
\hline \multirow[t]{4}{*}{ Flesh quality } & Taste & 1 & 2 & 1 & 2 \\
\hline & Colour & 1 & 1 & 1 & 1 \\
\hline & Lipids & 1 & 2 & 1 & 1 \\
\hline & Proteins & 1 & 1 & 1 & 2 \\
\hline
\end{tabular}

and Gaignon, unpublished data; OFIMER, 1999; Thomas, 2000). When a group of criteria was composed of only one parameter, its numeric value was used. On the other hand, when a group was composed of several parameters with different numeric scales, values were expressed in ranks. A global note was calculated for these families, taking into account the sum of the ranks of the different parameters, each of them being allocated of its own weighting coefficient. Then, this total was divided by the sum of the weighting coefficients. For their management using Electre III software, data were affected of a strict indifference threshold (SIT) of $10 \%$ and of a strict preference threshold (SPT) of $20 \%$. When the performances of two parameters were separated by a value lower than SIT, these parameters were not considered as different. On the other hand, they were considered as different when their performances were separated by a value higher than SPT. Between SIT and SPT, the difference between two parameters was progressively considered to be significantly established (Maystre et al., 1994). Table 4 shows the weight of each of the nine groups in the final classification of fish species according to the four profiles of the production-consumption line.

In order to test the robustness of the final classification, the effect of change of threshold (SIT from 2 to $20 \%$ and SPT from 15 to $40 \%$ ) on fish species ranking was assessed.

\section{Results}

At the end of the first phase, the mother population was composed of 8063 fish species. Three hundred and seventyfive species remained after the second phase. Because the whole sale price was not available in all selected species, the final classification was only carried out in 71 species. Fig. 1 presents fish classification species carried out using data presented in Table 5. Classification was established for each of the four profiles (respectively: production, transformation, distribution and consumption) and for the 32 species presenting the best position. This figure also presents the ranking obtained by adding the results recorded for the four

Table 4

Weighting coefficients (from 0 to 100) attributed to the nine groups of criteria according to the four profiles of the production-consumption chain

\begin{tabular}{|c|c|c|c|c|}
\hline Group & Production & Transformation & Distribution & Consumption \\
\hline Aquaculture potential & 7 & 0 & 0 & 0 \\
\hline Adaptation potential & 26 & 3 & 4 & 5 \\
\hline Growing out potential & 26 & 0 & 0 & 0 \\
\hline Rearing potential & 26 & 0 & 0 & 0 \\
\hline Transformation potential & 3 & 26 & 7 & 0 \\
\hline Practical use potential & 3 & 31 & 20 & 21 \\
\hline Image & 3 & 6 & 9 & 16 \\
\hline Consumption & 3 & 19 & 39 & 32 \\
\hline Flesh quality & 3 & 9 & 13 & 21 \\
\hline Total & 100 & 100 & 100 & 100 \\
\hline
\end{tabular}




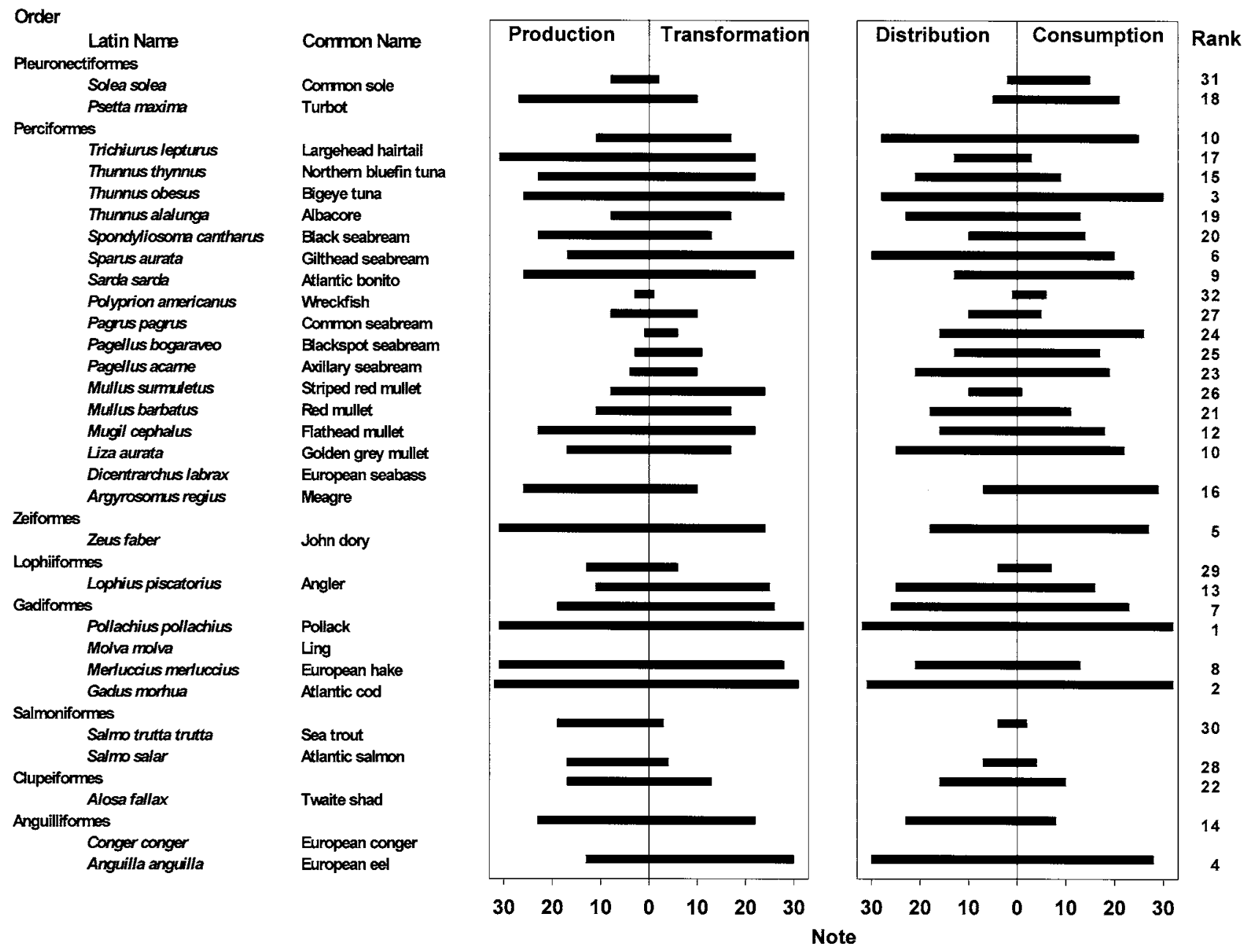

Fig. 1. Fish species classification for the four profiles (production, transformation, distribution and consumption). Control species already reared were inserted in this figure. Because this is more descriptive, notes represent $1 /$ species rank, highest notes corresponding to best positions. A classification is also presented adding the results recorded for the four profiles with a similar weight.

profiles. Because candidate species must be selected according to a balanced scheme taking into account the requirements of the four profiles of the production-consumption line, a similar weight was attributed to each of these profiles. In order to validate the accuracy of the selection method, the five control species whose production by aquaculture reaches more than $100 \mathrm{t}$, were inserted in this figure. Salmonids which are considered as control species, rank among high positions: Atlantic salmon (Salmo salar): 2nd and sea trout (Salmo trutta trutta): 8th.

Table 6 presents the final classification of fish candidate species for aquaculture development on the French Atlantic, the Channel and the North Sea coasts. Control species are not reported in this table. Cod was selected by this work as the first candidate for aquaculture development in northern parts of France. This rank was sustained by a very high position of this species in each of the four profiles. Other Gadiforms also present high positions: European hake (Merluccius merluccius): 6th and ling (Molva molva): 10th.

After modifying the strict indifference threshold and the strict preference threshold, no changes were observed in the rank of the first five species, confirming the stability of the final classification.

\section{Discussion}

The results recorded by the selection method proposed in this paper are strengthened by the following reasons: first, the selection was strongly supported by a fine knowledge of the demand of the main actors of the French aquacultural channel, the transformation and distribution channels and consumers attitude. The results of the inquiries conducted with the transformation and the distribution channels (Thomas, 2000) confirmed the evolution described by Paquotte (1998) of northern countries' consumer demands, mainly looking for ready to cook fish fillets. These changes are explained by modifications in lifestyles, urbanization and increasing interest in leisure. In order to fit this new demand, the present work focuses on the soaring market share of cuts of fish. Second, the method is based on a wide panel of 32 criteria taking into account not only biological 
Table 5

Scores recorded for the 32 species presenting the best position (no units for index or notes)

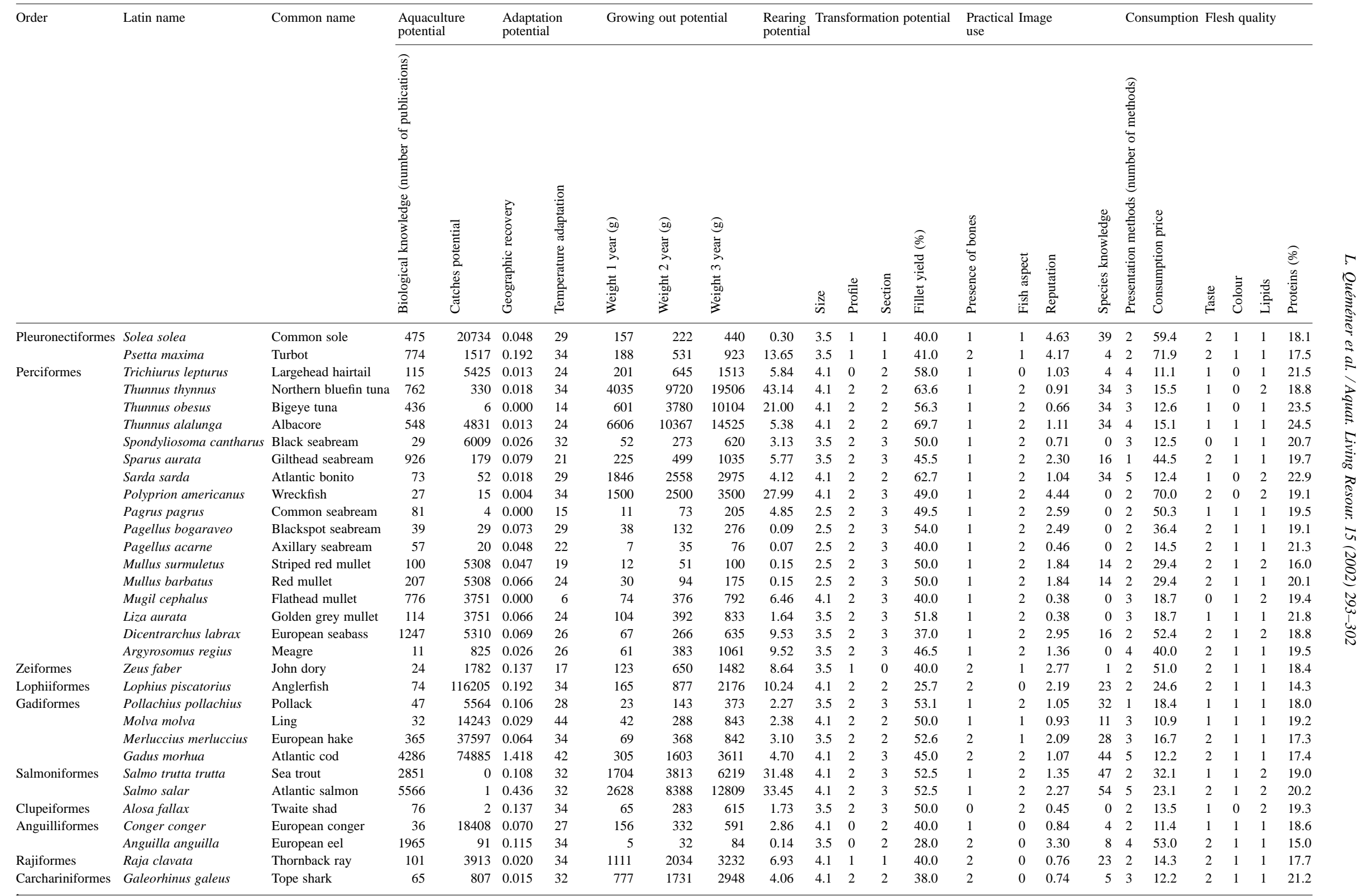


Table 6

Final classification of fish candidate species (control species were not included)

\begin{tabular}{|c|c|c|}
\hline Rank & Common name & Latin name \\
\hline 1 & Atlantic cod & Gadus morhua \\
\hline 2 & Albacore & Thunnus alalunga \\
\hline 3 & Tope shark & Galeorhinus galeus \\
\hline 4 & Anglerfish & Lophius piscatorius \\
\hline 5 & Atlantic bonito & Sarda sarda \\
\hline 6 & European hake & Merluccius merluccius \\
\hline 7 & Wreckfish & Polyprion americanus \\
\hline 8 & Meagre & Argyrosomus regius \\
\hline 8 & Largehead hairtail & Trichiurus lepturus \\
\hline 10 & Ling & Molva molva \\
\hline 11 & Thornback ray & Raja clavata \\
\hline 12 & Bigeye tuna & Thunnus obesus \\
\hline 13 & John dory & Zeus faber \\
\hline 14 & Northern bluefin tuna & Thunnus thynnus \\
\hline 15 & Black seabream & Spondyliosoma cantharus \\
\hline 16 & Golden grey mullet & Liza aurata \\
\hline 17 & European eel & Anguilla anguilla \\
\hline 18 & Red mullet & Mullus barbatus \\
\hline 19 & Axilliary seabream & Pagellus acarne \\
\hline 20 & Striped red mullet & Mullus surmuletus \\
\hline 21 & Flathead mullet & Mugil cephalus \\
\hline 22 & Blackspot seabream & Pagellus bogaraveo \\
\hline 23 & European conger & Conger conger \\
\hline 24 & Pollack & Pollachius pollachius \\
\hline 25 & Twaite shad & Alosa fallax \\
\hline 26 & Common sole & Solea solea \\
\hline 27 & Common seabream & Pagrus pagrus \\
\hline
\end{tabular}

but also fisheries and economical aspects. Third, data are extracted from a base containing information on 20000 species of the 25000 known fish species, and using some complementary sources of information such as wholesale fishmongers and scientific literature, so including the possibility to select a true "new species" whose rearing performances are unknown. Fourth, some information such as flesh taste could be rather subjective depending on local or personal preferences. However, information used in this work was extracted from admitted sources offering information on a wide number of species, so ensuring their objectiveness. Fifth, the present work selects new candidates using a three-step procedure containing elimination and then classification of subsequent phases rather than an a posteriori justification brought after the choice of a new species. Sixth, the large number of data and criteria are managed using Electre III, a multiple criteria decision making method that is currently used for decisions applied to environment and agricultural planning. Electre III introduces strict indifference threshold and strict preference threshold allowing to take into account a strong or week preference between species (Roy and Bouissou, 1993). Seventh, the final classification was carried out taking into account the requirements of the four profiles from fish production up to its consumption.

According to the study of Le François et al. (2002), a high rank was observed in the classification of the present work (Fig. 1) for control species such as Atlantic salmon (no. 2) and sea trout (no. 8), confirming the accuracy of the selection method proposed in both papers. However, the French production of seawater salmonids has not been well developed. Because France has mainly developed tourism, this could be partly explained by a high competition for coastal areas in this country. Furthermore, the synergistic effect of both high temperature and salinity of sea water leading to high mortalities during summer and also the low price of imported salmon from Norway and Scotland explained the absence of development of seawater salmonids aquaculture in France (Bœuf, 2000). Among control species, turbot was ranked 18th (Fig. 1), because of its profile and section badly adapted to the transformation requirements, its low fillet yield and its aspect distant from the classical fish morphology observed in species such as sea bass.

The addition of supplementary criteria would strengthen the selection of candidates for aquaculture and especially biological criteria such as the settlement of optimal temperature for rearing different fish species but also fecundity or the size of larvae. However, this information is most often not available in "new fish species". Furthermore, because the whole sale price was not available, the classification was only carried out using $20 \%$ of the species retained after Phase 2 of the selection.

Cod was selected by this work as the top candidate for aquaculture development on the western coasts of France (Table 6). The candidature of this species is sustained by many reasons: a good knowledge of its biology (4286 scientific references in ASFA base), a high possibility to catch juveniles and breeders in the wild, a low presence of bones in fillets and a good quality flesh. Furthermore, first successful experiences in aquaculture show that cod presents a high growth capacity in captivity ( $2 \mathrm{~kg}$ in 20 months; Huse, 1991) and that it is well adapted to water temperature ranging from 7 to $17{ }^{\circ} \mathrm{C}$, depending on fish weight (Björnsson et al., 2001). This preferundum coincides with sea water temperatures of the northern part of the west coasts of France. Cod presents a very good image and is well adapted to the requirements of the transformation channel. Furthermore, inquiries conducted with the French transformation and distribution channels showed that cod was the most interesting fish among sea water species for both sectors (Thomas, 2000).

The selection of cod by the present work coincides with the soaring interest in aquaculture of this species in northern European countries. Cod aquaculture expansion is sustained by a fall in wild catches, a rise in its selling prices, a high capacity of cod to be transformed and a wide market including northern and southern Europe and Latin America. In Norway, production of farmed cod is expected to reach $30000 \mathrm{t}$ in 10 years. Research into cod farming has also been carried out in Great Britain and Canada. In France, $58000 \mathrm{t}$ of cod were imported in 2001, representing a value of $217 \mathrm{M€}$ (Omnes, 2002)

The present work confirms the high value of Gadoids such as cod, European hake and ling for aquaculture on the 
French Atlantic, the Channel and the North Sea coasts. Apart from cod, research has been carried out in a few species belonging to this group, confirming their interest for aquaculture: haddock (Melanogrammus aeglefinus; Buckley et al., 2000) and pollack (Suquet et al., 2000). Then, the decrease of world catches of cod observed from 1968, and of European hake (FAO, 1998) sustains the need of aquaculture production of these species.

The final classification includes some original candidates such as tope shark (Galeorhinus galeus) or thornback ray (Raja clavata) whose potential has never been identified. This sustains the capacity of this work to select true "new species" without an a priori preference for some fish species using subjective criteria. However, the candidature of such species must be confirmed during a last phase, which is not included in this work. The rearing performances of the candidates selected in the present study will be verified during this final step. In particular, the optimal temperature for rearing, which is a key factor of farm profitability will be determined. Furthermore, a complete financial analysis of their rearing capacities will be conducted, including the financial consequences of some specific biological characteristics such as the low fecundity of tope shark or thornback ray.

Fish species belonging to the sparid family present low ranking: axilliary seabream (19th), blackspot seabream (22th) and common seabream (27th). This result can be explained by low values of geographic recovery, fillet yield, weight at 1,2 or 3 years old and rearing potential. Because of environmental conditions more adapted to these species, the rank of sparids will probably be increased in other geographical cases such as the Mediterranean one.

In conclusion, a selection method of new candidates for finfish aquaculture has been proposed, taking into account not only numerous and complementary aspects of the biology, fishery and economy but also the requirements of the production, transformation and distribution channels and of consumers. This method has been validated by selecting promising species such as cod and other Gadoids well adapted to environmental conditions of the northern west coasts of France. This method will help the selection of "new species" by farmers by strengthening their choice and by saving time, avoiding time consuming tests in species which do not step as good candidates for rearing. However, the rearing capacities of "new species" selected in this work must be evaluated by practical field tests carried out during a final phase. The results recorded during this step will strengthen the final choice of candidate species. The geographic case settled in this work covers a large area, presenting a wide range of water temperature. That is why, the determination of optimal temperature for rearing during this last step will precise the final choice of candidate species, according to the targeted environment. The successive steps of this selection method will now be applied to other cases, which can be geographical ones (Mediterranean, tropics) and technical ones (recirculating systems).

\section{Acknowledgements}

The authors want to thank P. Paquotte (OFIMER) for helpful comments on the manuscript. They are also grateful to S. Girard (IFREMER), C. Knockaert (IFREMER), C. Merrien (IFREMER) and J.L. Vallet (IFREMER) for fruitful discussions during the settlement of the selection method. Furthermore, they are also grateful to G. Dubois (Charlie Guennec Company), B. Jolivet (Furic Maree) and V. Mulak (CEVPM) for their data on fish flesh composition.

\section{References}

Avault, J.W., 1993. Ten requirements for culturing a "new" species: a checklist. Aquac. Mag. 19, 68-73.

Bartley, D.M., 1998. A precautionary approach for the introduction of new species in aquaculture. In: Enne, G., Greppi, G.F. (Eds.), New species for Mediterranean aquaculture. Proceedings of 33rd International Symposium on New Species for Mediterranean Aquaculture, Elsevier, 22-26 April1998, pp. 5-17.

Basurco, B., Abellan, B., 2000. Finfish species diversification in the context of Mediterranean marine fish farming development. Cah. Opt. Médit. 24, 9-26.

Benetti, D.D., Clark, A.M., Feeley, M.W., 1999. Feasibility of selected candidate species of marine fish for cage aquaculture development in the Gulf of Mexico with novel remote sensing techniques for improved offshore systems monitoring. In: Stickney, R.R. (Ed.), Proceedings of 3rd International Conference, Texas, Corpus Christi. Sea Grant College Program. Publ., Bryan, May 1998, 103-119.

Björnsson, B., Steinarsson, A., Oddgeirsson, M., 2001. Optimal temperature and feed conversion of immature cod (Gadus morhua L.). ICES J. Mar. Sci. 58, 29-38.

Bœuf, G., 2000. Present status of the French aquaculture. J. Jpn. Aquac. Soc. 48, 243-248.

Buckley, L.J., Bradley, T.M., Allen-Guilmette, J., 2000. Production, quality, and low temperature incubation of eggs of Atlantic cod Gadus morhua and haddock Melanogrammus aeglefinus in captivity. J. World Aquac. Soc. 31, 22-29.

Bykov, V.P., 2000. Chemical composition and processing properties of marine and ocean fishes. Handbook. VNIRO, Moscow.

COFREPECHE, 1996. Etude comparative des coefficients de conversion utilisés pour estimer le poids vif des captures de flottilles de pêche de l'Union, 1996. Final Report EU, Plouzané.

Davis, D.A., Arnold, C.R., Holt, G.J., 1998. Research summary on the potential mariculture species for the Gulf of Mexico. In: Stickney, R.R. (Ed.), Proceedings of 3rd International Conference, Texas, Corpus Christi. Sea Grant College Program. Publ., Bryan, 1998, pp. 120-131.

FAO, 1998. Fishery statistics vol. 86/1.

Fishbase 1998. Fishbase 98, CD-ROM, ICLARM, Manilla.

Frimodt, C., 1995a. Illustrated multilingual guide to the world's commercial coldwater fish. Fishing News Book, Oxford.

Frimodt, C., 1995b. Illustrated multilingual guide to the world's commercial warmwater fish. Fishing News Book, Oxford.

Hureau, J.C., 1996. Expert Center for Taxonomy Identification, Fishes of the North-Eastern Atlantic and the Mediterranean. The World Biodiversity Database, UNESCO.

Huse, I., 1991. Culturing of cod Gadus morhua. In: Mc Vey, J.P. (Ed.), CRC Handbook of mariculture, vol. II. Finfish Aquaculture, pp. 43-51.

Iioka, C., Kani, K., Nhhala, H., 2000. Present status and prospects of technical development of tuna sea-farming. Cah. Opt. Médit. 47, 275-286. 
Kentouri, M., Papandroulakis, N., Divanach, P., 1995. Species diversification in Greek finfish mariculture. Cah. Opt. Médit. 14, 129-136.

Le François, N.R., Lemieux, H., Blier, P.U., 2002. Biological and technical evaluation of the potential of marine and anadromous fish species for cold water mariculture. Aquac. Res. 33, 95-108.

Lensi, P., 1995. La politique de diversification de l'aquaculture en Corse. La démarche «nouvelles espèces ». Cah. Opt. Médit. 14, 137-148.

Maystre, L.Y., Pictet, J., Simos, J., 1994. Méthodes multicritères Electre. Presses polytechniques et universitaires romandes, Lausanne.

Muir, J.F., Young, J.A., 1998. Strategic issues in new species development for aquaculture. In: Enne, G., Greppi, G.F. (Eds.), New species for Mediterranean aquaculture, Proceedings of 33rd International Symposium on New Species for Mediterranean Aquaculture. Elsevier, April 1998, pp. 22-24.

New, M.B., 1999. Global aquaculture: current trends and challenges for the 21st century. World Aquac. 9, 8-79.

OFIMER, Office national interprofessionnel des produits de la mer et de l'aquaculture, 1999. Images, usages et attitudes en matière de poissons frais d'aquaculture. Vol 2: approche quantitative, Paris.
Omnes, M.H., 2002. La morue (Gadus morhua). Biologie, pêche, marché et potentiel aquacole. Ifremer, Plouzané.

Paquotte, P., 1998. New species in the Mediterranean aquaculture: is it an answer to the market demand for differentiated products? In: Enne, G., Greppi, G.F. (Eds.), New species for Mediterranean aquaculture, Proceedings of 23rd International Symposium on New Species for Mediterranean Aquaculture. Elsevier, 22-24 April 1998, pp. 73-83.

Quéro, J.C., Vayne, J.J., 1997. Les poissons de mer des pêches françaises. Delachaux \& Niestlé, Lausanne.

Roy, B., Bouissou, D., 1993. Aide multicritère à la décision: méthodes et cas. Economica, Paris.

Suquet, M., Parfouru, D., Paquotte, P., Girard, S., Gaignon, J.L., 2000. Method for selection of new marine fish species: the case of pollack (Pollachius pollachius). Cah. Opt. Médit. 47, 127-134.

Thomas, B.M., 2000. La morue serait un virage aquacole historique. Aqua Revue 92, 8-13.

Vallée, D., Zielniewicz, P., 1994. Electre III-IV, version 3.x Guide d'utilisation. Laboratoire d'analyse et modélisation de systèmes pour l'aide à la décision, Paris. 